\title{
Egalitarian men: stereotypes and discrimination in the labor market
}

\author{
Hyalle Abreu Viana; Ana Raquel Rosas Torres; José Luis Álvaro Estramiana
}

How to cite this article:

Abreu Viana, H., Rosas Torres, A.R., \& Álvaro Estramiana, J.L. (2020). Egalitarian men: stereotypes and discrimination in the labor market. Acta Colombiana de Psicologia, 23(2), 111-128. http://www.doi.org/10.14718/ACP.2020.23.2.6

Recibido, mayo 08/2019; Concepto de evaluación, septiembre 06/2019; Aceptado, febrero 11/2020

\author{
Hyalle Abreu Viana* \\ Universidade Federal da Paraíba, João Pessoa, Brasil \\ ORCID: https://orcid.org/0000-0003-4817-8839 \\ Ana Raquel Rosas Torres \\ Universidade Federal da Paraíba, João Pessoa, Brasil \\ ORCID: http://orcid.org/0000-0002-3161-0309 \\ José Luis Álvaro Estramiana \\ Universidad Complutense de Madrid, Madrid, España \\ ORCID: http://orcid.org/0000-0002-3017-0305
}

\begin{abstract}
This article aimed to analyze the stereotypes attributed to "egalitarian men", understood here as men who support gender equality in relation to domestic and family responsibilities as well as inclusion in the workforce. To do so, two studies were carried out. The first study investigated the attribution of stereotypes to egalitarian men through a single open question. A total of 250 university students participated in this study, of which $51.1 \%$ were male, and their average age was 21.5 years $(\mathrm{SD}=4.39)$. The second study analyzed the attribution of stereotypes to egalitarian or traditional men and women in a work context considered masculine. Participants included 221 university students with a mean age of 21.9 years $(\mathrm{SD}=4.19)$, the majority $(54.3 \%)$ being male. Taken together, the results of the two studies indicate that the egalitarian man is perceived as fragile and possibly homosexual. On the other hand, he is also seen as being more competent than traditional men. Keywords: Gender equality, gender stereotypes, gender discrimination.
\end{abstract}

\section{Hombres igualitarios: estereotipos y discriminación en el mercado laboral}

\begin{abstract}
Resumen
El presente estudio tuvo por objetivo analizar los estereotipos atribuidos a los "hombres igualitarios", aquí entendidos como hombres que defienden la igualdad de género en lo que refiere a las responsabilidades domésticas y familiares, así como en la inserción laboral. Para ello, se realizaron dos estudios: el primero para investigar la atribución de estereotipos sobre los hombres igualitarios por medio de una única pregunta abierta, en el que participaron 250 estudiantes universitarios con edad media de 21.5 años $(D E=4.39)$, de los cuales el $51.1 \%$ era del sexo masculino; y el segundo para analizar la atribución de estereotipos a hombres y mujeres igualitarios o tradicionales en un contexto laboral considerado masculino, que contó con la participación de 221 universitarios con edad media de 21.9 años $(D E=4.19)$, siendo la mayoría $(54.3 \%)$ del sexo masculino. En conjunto, los resultados de los dos estudios indican que el hombre igualitario es percibido como frágil y posiblemente homosexual; aunque, por otro lado, también es visto como más competente que los hombres tradicionales. Palabras clave: igualdad de género, estereotipos de género, discriminación de género.
\end{abstract}

\footnotetext{
Cidade Universitária, João Pessoa, 58051-900, Brasil. Tel.: +558332471097, hyalle_20@hotmail.com Esta investigación contó con el apoyo financiero de la Coordenação de Aperfeiçoamento de Pessoal de Nível Superior (CAPES).
} 
112

\section{Introduction}

Brazil ranks among the worst countries in terms of pay gaps between men and women. Data from the IBGE (2018) show that $21.5 \%$ of women and $15.6 \%$ of men from 25 to 44 years of age have completed college. However, although they are mostly in the higher education bracket and therefore more qualified for the labor market, women with this level of education receive, on average, $63.4 \%$ of the income of men with the same level of education. In 2016, for example, only $39.1 \%$ of management positions in Brazil were held by women. The situation is even more alarming when we consider that Brazil occupies the 95th position among the 149 countries studied regarding gender inequalities (World Economic Forum, 2017). Taken together, this evidence shows that gender disparity in Brazil is still quite strong.

However, given these obvious numbers of gender inequality in Brazil, one wonders what may be hindering the narrowing of these differences and the construction of a more egalitarian society for men and women. Studies conducted in Brazil suggest that the sexual division of roles (eg, domestic chores) is still very strong (Araújo \& Lombardi, 2013; Guedes \& Araújo, 2011; Hirata, 2015). This has intense repercussions both on family dynamics leading to women's physical and emotional overload - and on their professional life (El País, 2019; Fontoura, Rezende, Mostafa \& Lobato, 2017; Garcia-Alonso, Krentz, Lovich, Quickenden \& Taplett, 2019), making entry and stay in the labor market more difficult (Fontoura et al., 2017; Garcia-Alonso et al., 2019). However, these studies have in common the perspective of women: what are the consequences of sexist discrimination for women? Although we agree that studies of sexist discrimination should have this kind of emphasis, in this paper we take a slightly different perspective: why are men so resistant to change when it comes to the sexual division of roles? Two hypotheses can be formulated to answer this question.

Firstly, it could be the perception that more egalitarian relations between men and women may lead to the loss of certain privileges linked to the vision of a patriarchal society, in which it would be up to men to control economic, legal and political institutions and, to women, to take care of the house and children and to satisfy their husband's sexuality. This division of roles endowed men with a structural power that gave them the primacy of the dominant group and made the family a privileged locus for the reproduction of patriarchal values concerning male superiority and female inferiority.

In explaining sexist discrimination, Méndez (1995) and Zurutuza (1993) start from the assumption that the public versus private dichotomy, characteristic of patriarchal society, is constantly reinforced during the socialization process and would lead boys to develop images of masculinity associated with sexuality, the figure of the man as strong, dominating and responsible for supporting the family; and images of femininity related to the woman as a docile, submissive person and responsible for the household and the offspring.

Taken together, such images of male supremacy would form the psychosocial substrate that would justify attitudes of discrimination, oppression, and female domination. In short, sexist discrimination can be understood as an instrument used by patriarchal society to ensure gender differences, which is legitimized through the attitudes of female devaluation that are structured along the course of development, supported by legal, medical and social instruments that standardize them. Here, it is also important to keep in mind that patriarchalism would be one of the factors behind sexual violence against women and children. It is not by chance, for example, that Bott, Guedes, Goodwin, and Mendoza (2012) point out that the small but substantial proportions of young women in all surveys reported that their first intercourse was 'forced'. Husbands, partners, and boyfriends were the most commonly reported perpetrators in those surveys that measured this indicator. These results almost certainly represent the tip of the iceberg of the broader problem of child sexual abuse and unwanted sexual situations, in which the image of a woman as an object at the disposal of the man is probably hegemonic.

The second hypothesis would be the male difficulty in supporting egalitarianism between men and women for fear of themselves being discriminated as "feminine". Of course, these two possibilities are deeply intertwined, for the patriarchal view would produce images of men and women that somehow justify and perpetuate the status quo (Méndez, 1995, Zurutuza, 1993). Here it is important to clarify that when these authors speak of "images" they are referring to stereotypes, which, according to Fiske (1998), would be beliefs regarding the characteristics of social groups and their members, which are transmitted to society and can be accepted by one person as well as by groups. The view of stereotypes as justifiers of the system has been investigated since the year 2000 (Costa-Lopes, Dovidio, Pereira \& Jost, 2013; Pereira \& Vala, 2007; Pereira, Vala \& Costa-Lopes, 2010), although always emphasizing interracial and / or interethnic relationships. Here it is important to point out that together these works do not argue that social injustices, whether racial, ethnic or gender-related, can only be explained by stereotypes. What these papers advocate is that they would be important elements because they are both the product and justifiers of intergroup relationships, an idea originally defended by Henri Tajfel (1981). 
This paper aims to investigate this second hypothesis: how the egalitarian man is perceived, because, despite the large accumulation of works on the theme of gender discrimination (Benard \& Correl, 2010; Burgess, 2013; Connor \& Fiske, 2019; Connor \& Fiske, 2018), this aspect has been understudied. Thus, the general objective of this work was to analyze the stereotypes attributed to "egalitarian men" (Rudman, Mescher, \& Moss-Racusin, 2012), understood here as men who support gender equality with regard to domestic and family responsibilities as well as inclusion in the workforce.

The approach used to achieve this objective is that of intergroup relations, which assumes that the social belonging of the individual to certain social categories or groups directly influences distinct behaviors regarding majority or minority groups existing in a given society (Tajfel \& Turner, 1986). Stereotypes are conceived here as socially constructed and shared beliefs about the characteristics of social groups and their members, which would facilitate the understanding and explanation of social reality (Fiske, 1998). As such, stereotypes would be formed by means of a fit into distinct social categories, not only having the function of organizing the world, making it more understandable, but also serving to facilitate the justifications of intergroup differences (Amâncio, 2006; Costa-Lopes, Dovidio, Pereira \& Jost, 2013; Pereira \& Vala, 2007; Pereira, Vala \& CostaLopes, 2010).

Tajfel (1981) argued that the functions of stereotypes can be understood from two aspects: individual and collective. He also emphasizes that this taxonomy does not signify an opposition, because, for him, the individual would be part of the collective and the collective would also be part of the individual. Furthermore, according to Tajfel (1981), individual functions, besides simplifying reality, facilitating cognitive economy, also serve to protect the value system of the individual and thus maintain a positive self-image. This position is endorsed by more recent authors, such as Álvaro and Garrido (2006), Lima (2013), and Torres and Camino (2013). As for collective functions, Tajfel (1981) states that they can be for: a) explanation, due to the need to relate causes to complex and/or negative events, generally considering some vulnerable group as the cause; $b$ ) differentiation, acting in favor of a positive identification with the group; and c) social justification, serving to give arguments favorable to actions of social division based on categorization. Thus, stereotypes would be important elements for understanding a relevant aspect of gender relations: how egalitarian men are regarded and what are the consequences for them being seen as such.
Aiming to answer these questions, two studies were conducted. The first one, intended to investigate the attribution of stereotypical traits through a single open question; and the second study attempted to analyze the attribution of stereotypes to egalitarian or traditional men and women in a work context considered masculine. Traditional men and women are understood here as those who advocate differentiated social roles for men and women with regard to domestic, family, and work activities.

\section{Stereotypes and gender stereotypes}

In the studies presented here, we start from Tajfel's initial ideas (1978) in which he argues that intergroup relationships do not take place in a social vacuum. They happen in the social fabric that makes up a certain society, whose plot is permeated by ideologies that support them and that, in a way, justify the unequal relations between the various groups. In the specific case of this work, the interest lies in the relationships between men and women that are permeated by sexism, whose patriarchal view, as we have seen, attributes to men the mastery of the legal and juridical apparatus of a certain society and, to women, the submission to this apparatus.

For the purposes of this study and considering the intergroup relations perspective, gender stereotypes would generate accentuated differences between men and women (Barreto \& Ellemers, 2015), which would lead to a simplification of reality. While according to Ellemers (2018), gender is considered a principal resource in the perception of people, and is perceived as a binary categorization, in which there is a tendency to compare men to women and vice versa, anchoring any differences on the basis of the contrasts between them. Gender stereotypes have historically contributed to legitimizing and naturalizing inequality between the sexes, especially with regard to the invisibility of women in the public sphere (Garrido, Álvaro \& Torres, 2018). It is important to note here that taking this approach as an overview of the subject matter does not mean that the issue of sexist discrimination is being reduced to the existence of stereotypes. Our starting point is that the existence and permanence of gender stereotypes would be important aspects of this type of discrimination and the importance of which has not yet been sufficiently investigated.

An important way of analyzing gender stereotypes can be found in the studies by Pereira, Álvaro, and Garrido (2016) on the process of essentialization, demonstrating that although the "gender" category was less essentialized than the race category, when analyzing specifically the process of essentialization faced by men and women, women were more essentialized than men. Essentialization, 
114

according to these same authors, is the process of social categorization in which belief is placed in the existence of immutable characteristics of the target entities of the essentialist characterization, which differentiates them from those of other social categories. It is important to note that, in essentialist thinking, the categorization process, while sharing the assumption that it depends on the superficial similarities identified by the appearances of the members of a category, adds on the belief that the members of a group share more profound characteristics and that they differ from other categories (Gelman \& Wellman, 1991), which would allow one to assume the existence of an immutable "essence" for each social category. However, although the studies by Pereira, et al. (2016) show us the process by which men and women are seen, in stereotypical terms, in different ways, they do not specify the stereotypical contents that are attributed to each one and, more importantly, how this attribution is not only related to the gender category per se, but also to the positions related to the sexual division of roles assumed by men and women.

Considering studies on gender stereotype content, the model most commonly used by Social Psychology is the Stereotype Content Model (Fiske, Cuddy, Glick, \& Xu, 2002), which, according to Cuddy et al. (2009), would make it possible to know about the abilities of others to reach their goals and anticipate the intentions of others regarding ourselves. According to Fiske et al. (2002), stereotypes would be organized by means of two orthogonal dimensions, namely competence and sociability, which, combined with each other, would produce different forms of attitudes or prejudices.

Thus, while the competence dimension brings together aspects related to power, status, and instrumentality, the sociability dimension involves aspects such as expressiveness and affectivity. It is thus perceived that there is a dichotomization in the stereotypical content that can, depending on the context, modify the semantics of the stereotype, pointing to the ambivalent character of stereotypes (Fiske, $\mathrm{Xu}$, Cuddy \& Glick, 1999). These authors argue that a certain group, when perceived as having high values in sociability and low ones in competence, would provoke a prejudice of the paternalistic type (e.g., attitudes towards women). While those groups with high values in competence and low ones in sociability would produce envy and this would result in attitudes of avoidance. Thus, groups with low status would be perceived as highly sociable, but not competent (incapable and low-threat), while those with high status would be attributed high competence and low sociability.

Based on these ideas, Fiske et al. (2002) argue that the secondary role occupied by women in today's societies would also be the fruit of the social stereotype. Thus, according to these authors, because they are members of a low status group, they would also be perceived as more sociable and less competent. Taken together, these processes would underlie the maintenance of the privileges of the majority groups, in this case, men.

Meanwhile, the perception that high status groups are more competent and less sociable would help justify the social system and the resentment toward majority groups. Also, according to Fiske et al. (2002), the fact that the attribution is positive in one dimension does not necessarily contradict discrimination, since it may be functionally coherent with the negative stereotypical content of the other dimension. Thus, this model seeks to describe and predict how groups are ordered in a society, and tries to understand how the position of one group in this structure is closely related to the types of discrimination that its members may face (Bergsieker, Leslie, Constantine \& Fiske, 2012).

However, although the stereotype content model by Fiske et. al (2002) is the one most used in studies on this topic, Leach, Ellemers, and Barreto (2007), and LópezRodríguez, Cuadrado, and Navas (2013), upon reviewing it, proposed the addition of the morality dimension. This third dimension would be distinct from the sociability dimension, since according to these authors, they were already being considered in several studies as components of the same dimension (Fiske et al., 2002).

For Leach et al. (2007) the dimensions of morality and sociability would form a supra-ordered dimension, called benevolence, but they would be conceptually distinct dimensions, that is, the same group may be considered moral (honest) but not sociable (warm). Thus, for these authors, the three-dimensional model would remedy these discrepancies. On the other hand, the morality dimension has been considered as a positive evaluation alternative for minority groups, who would have difficulty in being perceived positively in terms of competence. These authors also point out that in their studies, the morality dimension was more important in the positive evaluation of the endogroup and less important in the positive evaluation of the outgroup.

Based on the ideas advocated by Leach et al. (2007) and the fact that the work presented here involves the study of stereotypical attributions to the members of a majority group, but that analyzes the processes involved in the defense of minority group positions (egalitarian man), we believe that using the three-dimensional model of stereotypes proposed by these authors would be more pertinent. This decision is based on the fact that this model makes it possible to evaluate the target - egalitarian man - in terms of a third dimension, morality, which would be important 
for the theme covered here, in the case of gender relations in family and work contexts.

On the other hand, research has shown that contact with counter-stereotypical people helps to reduce sexism (Bosak, Sczesny \& Eagly, 2012; Gocłowska, Crisp \& Labuschagne, 2012; Williams, Berdahl, \& Vandello, 2016). However, it has also shown that men who advocate gender equality, because they threaten the social hierarchy between the sexes, are subject to punishment for de-legitimizing the perception of the status quo, in which men would possess greater power and privilege than women (Rudman, Moss-Racusin, Phelan $\&$ Nauts, 2012). Thus, men who deviate from normative patterns of masculinity are described with stereotypes tied to low-status groups (weak, sensitive, feminine) or perceived as homosexual, even when there is no reason for this conclusion, such as when married to a woman (Anderson, 2009; Brescoll, Uhlmann, Moss-Racusin \& Sarnell, 2012; Heilman \& Wallen, 2010; Rudman \& Mescher, 2013; Rudman et al., 2012a; Viana, Souza \& Torres, 2018).

Rudman et al. (2012a) argue that men can use such discrimination or stigmas to deter other men from genderequality struggles, aiming to maintain the hierarchy between men and women and the status quo. For this reason, it is important to understand both the stereotypes constructed about the egalitarian man and also how he is evaluated in stereotypical terms, so that we may know whether in fact the stigma attached to this man can have an impact on his adherence and participation in movements that seek gender equality.

\section{Objectives and overview of the studies}

Given the above, the general objective of this work was to analyze the stereotypes attributed to "egalitarian men" (Rudman et al., 2012b), understood here as men who support gender equality with regard to domestic and family responsibilities as well as inclusion in the workforce. To achieve this objective, two studies were conducted. The first study aimed to investigate the attribution of stereotypes about men who support gender equality, through a single open question, and from there investigate the existence of stereotypical content related to the dimensions proposed by Fiske et al. (2002) and Cuadrado, López-Rodríguez, and Navas (2016): sociability, competence, and morality. The results of this study indicated that, in a general manner, egalitarian men are viewed through the stereotypical content most often attributed to women (Cuadrado, et al., 2016; Fiske et al., 2002). Based on these results, Study 2 aimed to specifically analyze whether the attribution of stereotypic traits is influenced by the positioning (egalitarian-traditional) and gender of the character (male or female) in a work context.
Finally, it is important to clarify that the studies reported here followed the ethics recommendations for research with humans in accordance with National Health Council Resolution 466/12.

\section{Method}

\section{Study 1}

This is a descriptive correlational study that aimed to investigate the attribution of stereotypes about men who defend gender equality, through a single open question, and from there investigate the existence of stereotypical content related to the three dimensions proposed by Fiske et al. (2002) and Cuadrado et al. (2016): sociability, competence, and morality. This objective was planned based on data found in the literature (Anderson, 2009; Rudman et al., 2012b; Viana et al., 2018) which show that men who defend gender equality are perceived as more feminine than those who do not defend it, and are also perceived to be more likely to be homosexual merely because they defend an ideal of equality (Anderson, 2009; Rudman et al., 2012b; Viana et al., 2018). Through the stereotypical content attributed to this egalitarian man it would be possible to reflect on the impact that egalitarian positioning can have on the hierarchical structure between men and women in society. Our expectation was that the egalitarian man would be seen through more feminine stereotypic traits.

In this study the discursive data were processed through textual analysis with the aid of computer programs that, according to Camargo and Justo (2013), prove relevant in studies about thoughts, opinions, beliefs, and symbolic content produced by a given phenomenon. For this purpose, IRAMUTEQ software, a free program for the R software environment, and in the python language, was used (Camargo \& Justo, 2013).

\section{Participants}

The sample was non-probabilistic, by convenience (Marôco, 2011), composed of 250 university students participating in the study, of which $51.1 \%$ were male. All of them were studying in a public university in the Brazilian Northeast.

Participants' ages ranged from 16 to 51 years $(M=$ 21.5 and $S D=4.39$ ). The inclusion criteria were a) to voluntarily accept participation in the study and b) to be a university student. 
116

\section{Instrument}

The questionnaire used was divided into two sections. The first contained only one open question: "How does Brazilian society perceive men who defend equality between men and women?" The second consisted of socio-demographic questions (gender, age, and study course).

This type of methodological strategy, known as the substitution technique (Abric, 2003; Guimelli \& Deschmaps, 2000), consists of asking not what one thinks, but how "one believes what society thinks". This strategy has at least two repercussions when it comes to studies on stereotypes and discrimination. First, it decreases the subject's level of involvement with their responses, thus allowing them to be freer to produce stereotypic content less marked by social desirability (Costa-Lopes \& Pereira, 2011). Second, as advocated by Chokier and Moliner (2006) and Flament and Milland (2010), the substitution technique places subjects in an explicit situation of social comparison, making them attribute opinions, thoughts, beliefs, and attitudes to the other in relation to a social object. Examples of this situation can be found in Camino, Silva, Machado and Pereira (2001) and Batista, Leite, Torres and Camino (2014), among others.

\section{Procedure}

The questionnaires were answered individually during collective application in the classroom. All participants signed the Informed Consent agreeing to participate voluntarily in the study.

\section{Data analysis}

Statistical methods were applied to textual data (Reinert Method), which is a procedure based on Descending Hierarchical Classification (DHC). Thus, the lexical analysis procedures were developed with the help of Iramuteq Interface de R pour lês Analyses Multidimensionnelles de Textes et de Questionnaires software (Camargo \& Justo, 2013; Ratinaud, 2009). DHC is characterized as a cluster analysis in which the text segments, after successive divisions, are grouped into homogeneous classes.

It is important to clarify that the Reinert method, or DHC, is a procedure based on automatic data processing statistical operations that provides results for further analytical processing and therefore does not represent the analysis itself. It is also important to clarify that this type of analysis does not deal with individual cases, but rather with those units that were relevant in the participants' discourse as a whole. This method facilitates the topical organization of the discourse found about the research object in the datasets, based on the construction of different lexical classes, but only through content analysis that can give meaning to its organization (see for example: Camino et al., 2013; Camino et al., 2014; Ferreira, et al., 2017). In this sense, it can be said that lexical analysis combines advantages of quantitative and qualitative approaches, but differs from Bardin's (1977) classical content analysis. For this reason, we believe that the data analysis technique used in the first study is consistent with the objective we intended to address and is pertinent to the type of data collected for the analysis.

According to Salviati (2017) and Camargo and Justo (2013), in the DHC the software processes the text in order to obtain classes formed by vocabularies that are significantly associated with that class (significance starts from $X^{2}=2$ ). In this way, the software, with the same correlation logic, uses divisions of the textual corpus, together with the list of reduced forms and the built-in dictionary, to present a hierarchical scheme of classes that, according to Salviati (2017) and Camargo and Justo (2013), makes it possible to infer the ideas that the textual corpus wishes to convey. In other words, the Iramuteq software aims to obtain classes of text segments (TS) with vocabulary similar to one another and vocabulary different from the TSs of the other classes. This analysis is based on lexical proximity and the idea that words used in a similar context are associated with the same lexical universe and are part of specific meanings or systems of representation (Salviati, 2017). However, the TSs are distributed according to their respective vocabulary and the set of terms is partitioned according to the frequency of the roots of the words.

Here it is important to clarify that the text segments of the corpus are classified according to their respective vocabularies and their set is divided according to the frequency of the reduced forms. From matrices crossing text segments and words (in repeated chi-square tests), the DHC method is applied and a stable and definitive classification is obtained (Reinert, 1990). This analysis aims to obtain classes of text segments that, at the same time, present a vocabulary similar to one another, and a vocabulary different from the text segments of other classes. From these matrix analyses, the software organizes the data analysis in a DHC dendrogram (Figure 1) that illustrates the relationships between classes.

\section{Results}

Through lexical analysis, after the reduction of the words to their roots, the corpus presented a total of 2,782 occurrences different words with 757 distinct forms. The Number of Texts was equal to 250, distributed into 250 Text Segments (TS), with a retention of $68.4 \%$ of the corpus. The Descending Hierarchical Classification (DHC), illustrated 
in the dendrogram in Figure 1, indicated the existence of three distinct classes.

For the descriptive analysis of the vocabulary of each class, Camargo and Justo (2013) suggest using two simultaneous criteria: a) keep attention on non-instrumental words with a frequency greater than the average frequency of the set of words of the total corpus (in our case 2,782 occurrences divided by 757 distinct forms, which results in the value of 3.67), and b) consider the words with $X^{2}$ of association to the class that are significant $(p<.05)$.

The DHC demonstrated that the division of the analysis corpus derived three distinct classes, which were distributed over two clusters, with Classes 1 and 2 being merged into a single cluster, and Class 3 forming the second cluster, which opposes the other two classes. Class 1 was the one that obtained the highest percentage of retention, equivalent to $61.4 \%$ of Text Segments; Class 2 had a $24 \%$ retention, and Class 3 obtained 14.6\%. In Figure 1, $X^{2}$ expresses the associative strength between the word and the class. The classes will be described following the order presented in the Descending Hierarchical Classification (DHC) and were named according to the interpretation of the Text Segments. Within each of the classes, the words are presented in descending order by the value of $X^{2}$ and, therefore, of the association with the class. It is also noted that each word has an associated $p$-value, which is related to the level of significance of the association of the word with the class, and therefore only the statistically significant vocabularies $(p \leq .05)$ were considered and included in the dendrogram of Figure 1.

Class 2, named "Stereotypes of Femininity", refers to the social representation of an effeminate man, perceived as weak, dominated by women and gay, thus corroborating the literature findings (Anderson, 2009; Rudman et al., 2012; Viana et al., 2018). In this class, the significance of the $X^{2}$ of the words (Figure 1 - first column) How/As, Effeminate, Weak, Feminine, Turn, Less, Generally, and Stereotype indicates that they organize its semantic content. Thus, one can see content of sociability stereotypes of (Cuadrado et al., 2016; Fiske et al., 2002;), for example, the fact that they are

"How does Brazilian society perceive men who defend equality between men and women?"

\begin{tabular}{|c|c|c|c|c|c|}
\hline \multirow{2}{*}{\multicolumn{2}{|c|}{$\begin{array}{c}\text { Class } 2 \\
\text { Stereotypes of } \\
\text { feminity }\end{array}$}} & \multirow{2}{*}{\multicolumn{2}{|c|}{$\begin{array}{c}\text { Class } 1 \\
\text { Ambivalence of } \\
\text { acceptance }\end{array}$}} & \multirow{2}{*}{\multicolumn{2}{|c|}{$\begin{array}{c}\text { Class } 3 \\
\text { Prejudice and threat } \\
\text { to masculinity } \\
\end{array}$}} \\
\hline & & & & & \\
\hline \multicolumn{2}{|c|}{$24 \%$} & \multicolumn{2}{|c|}{$61.4 \%$} & \multicolumn{2}{|c|}{$14.6 \%$} \\
\hline Word & $\chi^{2}$ & Word & $\chi^{2}$ & Word & $\chi^{2}$ \\
\hline How / As & 62.1 & No / Not & 14.4 & Form & 91.3 \\
\hline Effeminate & 31.9 & Equality & 13.4 & Negative & 54.8 \\
\hline Weak & 28.4 & Man & 10.4 & Prejudice & 42.5 \\
\hline Femenine & 9.5 & Very & 10.0 & Way & 30.1 \\
\hline Turn & 6.2 & Society & 8.2 & Evaluate & 10.7 \\
\hline Less & 5.8 & Belive & 7.8 & Depend & 4.1 \\
\hline Generally & 5.8 & Woman & 6.9 & $\mathrm{De}$ & 25.7 \\
\hline \multirow[t]{4}{*}{ Stereotype } & 5.8 & Struggle & 6.7 & & \\
\hline & & Male chauvinist & 6.7 & & \\
\hline & & Prejudice & 5.9 & & \\
\hline & & Feminist & 4.9 & & \\
\hline
\end{tabular}

Figure 1. DHC of the discourse about the perception of men who support equality between men and women. Source: Figure developed by the authors. Study data. 
perceived as less men, sensitive, incompetent, submissive, etc. The following are examples of discourse on this class: "men engaged in these struggles are effeminate, sensitive men" and "are seen as incompetent."

In Class 1, called "Ambivalence of Acceptance", the content is more grounded in the consequences that men are subject to when they decide to engage in a struggle for rights that, in the first instance, would not be their own. In this class, the significance of the $X^{2}$ of the words (Figure 1 - second column) No/Not, Equality, Man, Very, Society, Believe, Women, Struggle, Male chauvinist, Prejudice, and Feminist indicates that they organize its semantic content.

Thus, the content varies from the perceived threat of this man to the women's right to speak, as if wanting to "steal" women's protagonism in positioning himself as an egalitarian man. So they are often discredited and stereotyped as feminine, homosexual, and are despised for fighting for equality between men and women due to the machismo present in Brazilian society. On the other hand, according to the participants, there is also a positive image of these men, especially on the part of women, who would see such men as allies for the achievement of equality. Thus, often these men would be seen by them as examples of dignity and of righteous people. Finally, it is important to point out that in this class many stereotypical contents related to morality appeared (Cuadrado et al., 2016), such as: "he is evaluated as a good person, as long as he does not silence those who really deserve to speak"; "One part, generally women, think it's beautiful [...] another part, mostly men, thinks it's effeminate."

While Class 3, named "Prejudice and threat to masculinity", carries a negative image of the egalitarian man, thus alienating the male population from this social responsibility in view of the prejudice they are subject to in a society marked by patriarchalism and machismo. In this class, the significance of the $X^{2}$ of the words (Figure 1 - third column) Form, Negative, Prejudiced, Way, Evaluate, Depend, Of/ From indicates that they organize its semantic content. Thus, according to the participants, society tends to criticize these men with prejudiced jokes and insults, and this is due in part to the negative view of the feminist movement, which many believe is aggressive and unruly. In this third class, content is seen tied to the competence dimension (Fiske et al., 2002; Cuadrado et al., 2016) that anchors this image to the perceived threat to the male group status in society. This perceived threat would be a consequence, according to the participants, of the fact that egalitarian men defend ideals that favor the women's group, thereby jeopardizing the notion of male supremacy and patriarchalism control over them. However, an attempt was seen to delegitimize the struggle of these egalitarian men, questioning their competence and masculinity, with the intent of maintaining the status quo. Examples of discourse from this class are: "in a negative way, tending to alienate the male population from the movement and ridiculing those who are part of it", and "the patriarchal character of society makes the view of these people somewhat negative."

\section{Partial discussion}

In this first study it could be observed that in the participants' perception, egalitarian men are seen as sensitive, incompetent, feminine, that is, some contents related to the sociability dimension of the stereotype content model by Fiske et al. (2002) and Cuadrado et al. (2016) are attributed to these men. Together, these results corroborate the findings by Anderson (2009), Rudman et al. (2012), and Viana et al. (2018), who show that men who support gender equality are perceived as more feminine than normative men.

This first study further demonstrates that egalitarian men suffer from the normative pressures related to gender roles and are discriminated against for supporting an ideal that can threaten the status of the men's group in the social hierarchy. It is also interesting to reflect on the pressure of machismo intrinsically present in these results, reflected, for example, when participants say that egalitarian men are a threat to women's right to speak, that they are more feminine, incompetent, and unreliable. We believe that these arguments are perhaps an attempt to keep men away from this cause, that is perceived by the participants as a responsibility that is not theirs, as well as to try to maintain the status quo, as if they wanted to tell implicitly that this "is not a man's thing." In these terms it is found that there is a relationship between these results and competence stereotypes (Cuadrado et al., 2016; Fiske et al., 2002), since some of these arguments may serve to demotivate men from being egalitarian. If they are like this, they will not be seen like the other men in society who, according to the studies on gender stereotypes, are perceived as competent and respected.

However, while perceiving the stereotypical view of egalitarian men as a threat to masculinity and feminism itself, it is also found that for some participants this man who supports gender equality should be well regarded because he would help to achieve equal rights, and this should be seen as everyone's struggle and not just that of women. In this case, egalitarian men are perceived as extremely positive, fair, and dignified, attributes characteristic of the morality dimension of Cuadrado et al. (2016). 
Based on these results, the second study was planned, which aimed to specifically analyze whether the attribution of stereotypical traits is influenced by the positioning (egalitarian-traditional) and gender of the character (male or female) in the work context. For this purpose, a 2 X 2 design and a masculine work context were used. This context was chosen because, according to Moreno (2017), from January to August of 2017, of the 20,813 people who were registered with the Federal Council of Engineers and Agronomists (Confea), as civil engineers, only $28.1 \%$ were female. This author also points out that in 2015 the percentage of women enrolled in the civil engineering degree program was $30.3 \%$. According to her, in the job market this percentage drops to $26.9 \%$. On the other hand, the study developed by Viana (2016) showed that university courses on the exact sciences area are typically categorized as being masculine (e.g., engineering, physics, mathematics).

\section{Study 2}

After analyzing the stereotypical content attributed to the egalitarian man and the proof of existence of stereotypical attributes tied to the dimensions of sociability, morality, and competence, we were interested in analyzing the attribution of stereotypes to egalitarian or traditional men and women in a work context considered masculine. This masculine context (engineers at a construction company) was chosen based on the study developed by Viana (2016) and on data reported by Moreno (2017) showing that professions such as engineering are mostly occupied by men. Thus, as in typically masculine contexts, men are perceived as more competent and less sociable than women (Fiske et al., 2002; Viana, 2016; Viana et al., 2018). It is believed that in this context, egalitarian men will be under greater normative pressure and consequently will be perceived as less competent and more sociable than men who do not support maternity leave, because by taking an egalitarian position, they could lose their status of superiority.

Thus, the second study of this work tested the general hypothesis that the positioning and the gender of the character will affect the attribution of stereotypical traits. So we hypothesize that:

H1) Men who call themselves egalitarian, defending a right won by the feminist movement, such as the right to maternity leave, should be perceived as more sociable than women who defend that same right and men who oppose the right to maternity leave (Anderson, 2009; Rudman et al., 2012b). This is due to the fact that previous research (Anderson,
2009; Rudman et al., 2012a,b) shows that egalitarian men are stereotyped with feminine or homosexual attributes, and thus should also be perceived as more sociable (Fiske, et al., 2002). While egalitarian women, in a masculine context, will be perceived as more competent than sociable, corroborating the model of Fiske et al. (2002).

H2) On the other hand, men who are traditional and against maternity leave should be perceived as more competent than egalitarian men. This is because in the typically masculine context presented in the instrument, it is already expected that the traditional man is perceived as more competent (see Fiske et al., 2002 and Viana et al., 2018), but the egalitarian man will be perceived as a black sheep (Pinto, Marques, Levine \& Abrams, 2016), being perceived more negatively in the competence dimension. According to these authors, all groups have prescriptive norms that dictate how their members should behave. Thus, the basic premise is that the group member who opposes the generic and prescriptive norms of their group (deviant or counter-normative member) threatens the positive social identity of others in the group, but the members who defend the norms (normative) reinforce this identity (Marques, Yzerbyt and Leyens, 1988). Thus, according to Pinto et al. (2016), when there is a salient norm and some individual deviates from this norm (counter-normative), this individual is evaluated more negatively than the normative individual. The black sheep effect occurs, therefore, as a strategy to protect intragroup dynamics.

H3) Regarding the morality dimension, we have the hypothesis that, because it is a dimension that serves both to qualify minority groups and increase ingroup positivity (Cuadrado et al., 2016; LópezRodríguez et al., 2013), egalitarian characters will be seen as more moral than traditional ones because this dimension, although very close to the sociability dimension, differs from it since, according to Brambilla et al. (2011) morality has a rather strong power in forming impressions both at the ingroup level and in relation to other groups. Authors such as Brambilla et al. (2012) demonstrated that morality was a more effective predictor in relation to sociability and competence in the overall assessment of a group of unknown immigrants. For this reason, we believe that by defending a just and positive ideal for the advancement of society, egalitarian individuals will stand out in this dimension. 


\section{Method Study 2}

This is a study with a $2 \mathrm{X} 2$ experimental design in which the gender of the character (man or woman) and the type of positioning (Egalitarian or Traditional) were manipulated, with the factors varying between participants.

\section{Participants}

The sample was non-probabilistic, by convenience (Marôco, 2011), composed of 221 university students, the majority ( $54.3 \%$ ) being male, equally distributed between courses considered masculine or feminine (Viana, 2016). Participant ages ranged from 17 to 48 years $(M=21.89$ and $S D=4.19)$. All of them were studying in a public university in the Brazilian Northeast. It is important to clarify that this context was used because previous studies (Viana, 2016; Viana et al., 2018) show that the type of work context (masculine or feminine) influences both the attribution of stereotypes and the evaluation of the professional. Participants were randomly assigned to one of four experimental conditions as shown in Table 1.

Table 1.

Number of participants by experimental condition

\begin{tabular}{cccc}
\hline Positioning & Man & Woman & Total \\
\hline Egalitarian & 56 & 56 & 112 \\
Traditional & 55 & 54 & 109 \\
Total & 111 & 110 & 221 \\
\hline
\end{tabular}

Inclusion criteria were: a) to voluntarily accept participation in the study and b) to be a university student.

\section{Instrument}

First, a situation was presented to participants in which a man (or a woman) was defending: a) the right to maternity leave because it is a right that should be guaranteed at all costs, regardless of the woman's profession and the position she holds (egalitarian situation) or (b) leave is not a right but a perk and women take advantage of this time to do other things, adversely affecting the companies that need to continue to pay their salaries monthly throughout the period of leave (traditional situation). Each participant responded to only one of the four conditions.

Then participants responded to the following sections:

a. Stereotypical perception. The scale with eighteen items in the version developed by Cuadrado et al. (2016) was used. These authors draw on the works of Fiske et al. (2002), Leach et al. (2007), and Brambilla et al. (2011), whose studies confirmed the three-factor structure formed by the sociability, morality, and competence dimensions of this instrument, with satisfactory internal consistency indices. In the study by Cuadrado et al. (2016) the scale was applied to evaluate six distinct groups in these dimensions and, for all of them, Cronbach's alphas above .85 were calculated.

For this study, the items were translated from Spanish into Portuguese with the help of judges. Participants were told: "Think of (name of the target of the story read) and say to what extent you believe each of the following characteristics describes him/her". Each dimension was evaluated with six items: a) morality (honest, trustworthy, sincere, courteous, fair, well-intentioned), b) sociability (kind, friendly, attentive, warm, agreeable, good character), and c) competence (secure, intelligent, skilled, efficient, capable, competent). After factor analysis some items presented low factor loadings (below .30) and had to be excluded from the analysis. They were: attentive and good character from the sociability factor; courteous and fair from the morality factor; and the secure item from the competence factor. Thus the stereotype scale became more parsimonious, with satisfactory internal consistency indicators for the three dimensions: morality $(\alpha=.78)$, sociability $(\alpha=.81)$, and competence $(\alpha=.89)$, corresponding respectively to 16.4 , 22.5 , and $20.0 \%$ of the total variance.

b. Sociodemographic characteristics (gender and age). At the end of the questionnaire, two questions were included to ascertain whether the experimental manipulation had produced an effect. The first asked about the gender of the character in the situation presented. The second asked about the extent to which the participant considered the character to be egalitarian or traditional with regard to women's struggles. It is highlighted that the percentage of correct answers to these questions was higher than $98 \%$ and only these participants were considered in the study.

\section{Procedures}

The questionnaires were answered individually during collective application in the classroom, after consent from the teacher. All participants signed the Informed Consent agreeing to participate voluntarily in the study. After accepting participation, the students received the previously randomized questionnaires.

\section{Data analysis}

In order to verify the effect of the experimental manipulation on the dependent variables (sociability, morality, and competence stereotypes), a multivariate analysis of variance (MANOVA) was performed, and descriptive statistics were also calculated to characterize the sample in question. 
According to Field (2006), for the results of MANOVA to be considered valid, the following assumptions must be met: (1) independence of observations; (2) the sample must be random; (3) multivariate normality: inferred through the verification of normality for each dependent variable considering the groups of the independent variable; (4) homogeneity of variance-covariance matrices: measured by Box's M Test. To verify the presence of multivariate normality, the result of the Shapiro-Wilk Test was considered to be more accurate than the Kolmogorov-Smirnov Test (Field, 2006). This was combined with visual inspection of normality in the Histograms, Q-Q Plots, and Box Plots. The Shapiro-Wilk test gave indications that lead to rejection of the null hypothesis of normal distribution at the significance level of 5\%. However, the more flexible skewness and kurtosis measurements allow verification of normality of the data distribution, since the skewness values are greater than -1 and less than 1 . The last criterion was obtained through Box's M Test (Hair et al., 2010), which by being non-significant (Box's $M=26.14, p=$ .11 ), indicates that there is homogeneity in the variancecovariance matrices. Additionally, Tabachnick and Fidell (2001) nevertheless suggest that if large samples produce large variances and covariances, the probabilistic values will be conservative (and the significance values found will be reliable). Taken together, these results show that the conditions for MANOVA are satisfied.

\section{Results}

\section{Stereotype attribution to egalitarian women and men}

Previous analyses have shown that the participant's gender does not affect the results, thus being excluded from the analyses. The design used in the MANOVA included only the variables manipulated in the scenario presented: the character's gender and type of positioning (egalitarian, in favor of the leave, versus traditional, against the leave). There was a significant multivariate effect of the character's gender, Wilks's Lambda $=.96, F(3,220)=3.14, p=.03$, and the character's position, Wilks's Lambda $=.58, F(3,220)=$ $51.05, p=.01$. There was also a multivariate effect of the interaction between the character's gender and the character's position, Wilks's Lambda $=.96, F(3,220)=3.21, p=.02$. The character's gender provoked statistically significant differences only in the competence stereotype, $F(1,217)=$ $6.07, p=.01$, indicating that in general the female character was perceived as more competent $(M=3.6 ; S D=0.72)$ than the male character $(M=3.4 ; S D=0.73)$.
However, the character's position generated statistically significant differences in the three stereotypical dimensions: sociability $F(, 217)=142.30, p=.01$, morality, $F(1,217)$ $=66.25, p=.01)$, and competence, $F(1,217)=74.02, p=$ .01 . In general, the egalitarian targets, advocates of maternity leave, were perceived more positively in the three stereotypical dimensions, that is, they were perceived as more sociable, moral, and competent (Table 2).

Table 2.

Means (and Standard Deviations) of Stereotypical perception in the dimensions of sociability, morality, and competence by the positioning of the character.

\begin{tabular}{cccc}
\hline & Sociability & Morality & Competence \\
\hline \multirow{2}{*}{ Egalitarian } & $\mathrm{M}=3.49^{*}$ & $\mathrm{M}=4.02^{*}$ & $\mathrm{M}=3.92^{*}$ \\
& $(\mathrm{SD}=0.75)$ & $(\mathrm{SD}=0.81)$ & $(\mathrm{SD}=0.78)$ \\
Traditional & $\mathrm{M}=2.29^{*}$ & $\mathrm{M}=3.14^{*}$ & $\mathrm{M}=3.08^{*}$ \\
& $(\mathrm{SD}=0.78)$ & $(\mathrm{SD}=0.79)$ & $(\mathrm{SD}=0.69)$ \\
\hline
\end{tabular}

Note. The asterisk $(*)$ indicates statistical significance between the means $(\mathrm{p}<.05)$.

In relation to the interaction between the character's position and the character's gender, there are statistically significant differences in the sociability dimension only in the condition in which the targets support maternity leave (Egalitarian), $F(1,217)=4.92, p=.03$ (see Table 2 and Figure 2), showing that the egalitarian man supporting maternity leave is perceived as more sociable than the woman with the same position and the traditional man against the leave. The dimension of morality was not influenced by these variables.

The results of these interactions can also be observed in the graphs of Figure 2.

With respect to competence, there are marginally significant differences only in the condition in which the targets are against maternity leave (Traditional), $F(1,217)$ $=3.65, p=.06$, indicating that in this condition, traditional women are perceived as more competent than traditional men who are equally opposed to maternity leave (Table 3 and Figure 2).

It is also important to note that we predicted that the egalitarian man supporting maternity leave would be perceived more negatively in the competence dimension than the non-egalitarian man against the leave. However, the results demonstrate the opposite, that the egalitarian man, the supporter of maternity leave, was perceived as more competent than the traditional men, and this difference is statistically significant.

Finally, the fact that the egalitarian woman, who supports maternity leave, was evaluated more positively in the 
Table 3.

Means (and Standard Deviations) of Stereotypical perception in the dimensions of sociability, morality, and competence by the positioning of the character and the gender of the character.

\begin{tabular}{ccccccc}
\hline & \multicolumn{2}{c}{ Sociability } & \multicolumn{2}{c}{ Morality } & \multicolumn{2}{c}{ Competence } \\
\cline { 2 - 4 } & Man & Woman & Man & Woman & Man & Woman \\
\hline \multirow{2}{*}{ Egalitarian } & $\mathrm{M}=3.66^{*}(\mathrm{SD}$ & $\mathrm{M}=3.34^{*}(\mathrm{SD}$ & $\mathrm{M}=3.96(\mathrm{SD}=$ & $\mathrm{M}=4.08(\mathrm{SD}=$ & $\mathrm{M}=3.81(\mathrm{SD}=$ & $\mathrm{M}=4.03$ \\
& $=.76)$ & $=.69)$ & $.75)$ & $.86)$ & $.78)$ & $(\mathrm{SD}=.77)$ \\
\hline \multirow{2}{*}{ Traditional } & $\mathrm{M}=2.18(\mathrm{SD}=$ & $\mathrm{M}=2.40(\mathrm{SD}=$ & $\mathrm{M}=3.09(\mathrm{SD}=$ & $\mathrm{M}=3.19(\mathrm{SD}=$ & $\mathrm{M}=2.94^{*}(\mathrm{SD}$ & $\mathrm{M}=3.21^{*}$ \\
& $.77)$ & $.78)$ & $.79)$ & $.79)$ & $=.66)$ & $(\mathrm{SD}=.69)$ \\
\hline
\end{tabular}

Note. The asterisk $(*)$ indicates statistical significance between the means $(p<.05)$.
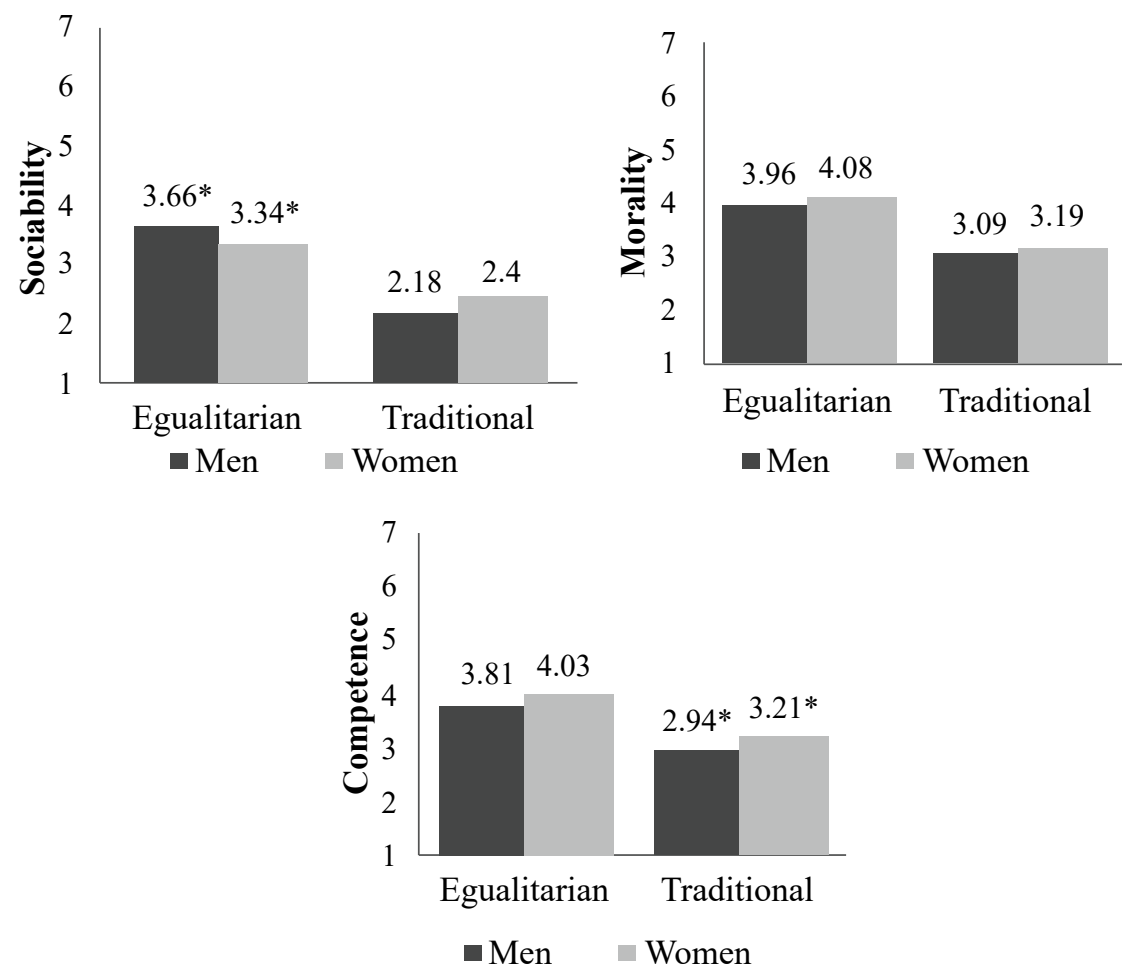

Figure 2. Stereotypical perception in the dimensions of sociability, morality, and competence by the positioning of the character and the gender of the character. The asterisk $(*)$ indicates statistical significance between the means $(p<.05)$.

competence dimension than the egalitarian man, should also be highlighted, although this difference is not statistically significant.

\section{Discussion}

The results of Study 1 demonstrated the existence of stereotypical content related to the three dimensions proposed by Cuadrado et al. (2016): sociability, competence, and morality. Taken together, these results indicate that the egalitarian man is perceived in a negative way and enveloped in suspicions. Thus, according to the participants, men would react with prejudice and stereotypes of femininity linking the egalitarian man to homosexuals in a negative way. While women, according to the participants, would perceive him either as a threat to feminists' right to speak or as an important ally in the struggle for equal rights.

In this study it was also found that the classes that gave rise to the dendrogram brought elements that present the egalitarian man as quite sociable and feminine. According to some participants, this man is also perceived as an example 
of dignity and morality for contributing to gender equality, but he is seen as not very competent (viewed with distrust by other men and victims of prejudice), a fact that can lead to men's avoidance or lack of interest in participating in these struggles. However, men who support gender equality, because they are perceived as more sociable than competent, may also be victims of the discrimination inherent to low status groups (Fiske et al., 2002).

Study 2 verified that the perception of the targets in terms of sociability, morality, and competence is influenced both by the type of positioning (egalitarian or traditional) and by the gender of the targets (man or woman). However, the participant's gender had no influence on the results found. The fact that the gender of the participants (men and women) did not influence the results does not compromise the conclusions we can reach in this paper because, according to Fiske (1998), stereotypes are socially shared beliefs that can be accepted by people and individuals as well as groups. Thus, we will present the main results found without comparing the gender of the participants, but according to the type of positioning and gender of the character presented in the experimental situation used.

In general, the egalitarian men were perceived as more sociable than egalitarian women and traditional men, corroborating our first hypothesis (H1). Differently from what was expected, however, egalitarian men were perceived as more competent than traditional men, a result contrary to $\mathrm{H} 2$. This result is similar to that found by Albuquerque (in press), who demonstrates that men who use paternity leave are more positively evaluated in the competence dimension.

This result, together with that of the sociability dimension (H1), leads to the conclusion that investigations into the attribution of stereotypical traits should take into account variables concerning the relationships between the groups belonged to (male or female, see Fiske et al., 1999; 2002), but also those regarding more ideological levels, such as egalitarian or traditional positions (Doise, 2002). In other words, together, these results demonstrate the importance of connecting different levels of analysis (Doise, 2002) to understand phenomena that are the product of intergroup relations, such as stereotypes (Tajfel, 1981). It is also important to reflect that, according to the Stereotype Content Model (Fiske et al., 2002), the group perceived as highly sociable is an admirable group, but one that is poorly respected and, therefore, to think and act in accordance with this belief favors increasing inequality between social groups, in our case between the men and women groups.

Regarding women, the fact that they were assessed more positively in the competence dimension, regardless of their positioning, was unexpected given the predictions of the constant model in the literature in this respect, theorizing exactly the opposite (Eagly \& Karau, 2002; Fiske et al., 2002). One possible explanation for this result is that although the stereotype content model by Fiske et al. (2002) empirically demonstrates that the group of men is perceived as more competent than the group of normative women, in the research scenario presented to the participants, the woman was an engineer in a high status company, i.e., she was counter-normative, as she was placed in a professional context typically masculine. Thus, she can be considered counter-stereotypical because she "escapes" the normative patterns and the expectations tied to traditional gender roles, and thus, moves closer to the outgroup (see Viana, 2016 and Viana et al., 2018). Therefore, when she opposes maternity leave, she is perceived as more competent than the man who is already expected to position himself in this way (Table 3). This result shows, among other things, that women need to become masculine so they can take on leadership roles or typically male professional spaces (Lima, 2011; Nogueira, 2010).

Similar results were found by Eagly and Steffen (1984), who demonstrated that participants tended to perceive women in male-dominated roles as more competent than men. These authors comment that this effect may be the result of the belief that if women explicitly chose that role, it is because they would have a dispositional inclination for these male-dominated activities, i.e., if they chose this profession it is because they are very competent and in addition, they would have overcome the normative pressures working against these choices.

With the dimension of sociability, the reverse is true: the man is the one who is counter-stereotypical (egalitarian, defender of a "women's right"), moving closer to the outgroup (women) and moving away from the endogroup (men). For this reason, he is perceived as having more sociable or feminine stereotypical attributes (Anderson, 2009; Rudman et al., 2012a). Within this same perspective, Eagly and Steffen (1984) also demonstrated in their work that counter-stereotypical men were perceived as more sociable. According to these authors, this perception is due to the choice made by these men and to their having faced the normative barrier of stereotypes, leading the participants to believe that they are, in fact, more sociable because they chose to carry out an activity dominated by women.

Given these results, and based on the literature that has shown that men who adhere to women's rights movements are stigmatized and stereotyped with more feminine attributes and/or are perceived as probable homosexuals (Study 1 of this work; Anderson, 2009; Rudman et al., 2012a; Viana et al., 2018), we believe that being an egalitarian man can also lead to discrimination against these individuals in work contexts. Thus, as contextualized in the introduction 
of this paper, the fear of being discriminated could hinder male support on gender equality issues, and it is precisely because of this fear that patriarchal ideology and stereotypes of sexual roles maintain and justify the status quo (Mendez, 1995; Zurutuza, 1993).

If that is true, it can help us understand one of the barriers to achieving gender equality. In other words, if men, who are members of the group that enjoys greater privileges in the social hierarchy, position themselves as egalitarian for gender issues, and for this reason suffer retaliation (black sheep effect, Marques et al., 1988; Pinto et al., 2016), this can serve as a justification for the non-adherence of men in the struggle for gender equality. Of course, gender inequality is not being reduced to a single aspect, but it is proposed that the results found here contribute to its maintenance.

Taken together, the results presented here point to the importance of investigating the stereotype processes tied to gender relations. Specifically, we are dealing with an aspect that has been little investigated, which is how the man who defends gender equality is seen. Since stereotypes include, among their social functions, legitimizing prejudice and discrimination while maintaining the status quo (Álvaro \& Garrido, 2006; Tajfel, 1981; Torres \& Camino, 2013), the results indicate that in the quest to reduce discrimination against women, it is also important for us to work on the stereotypes linked to men, in order to change their image, humanizing it with regard to the expression of affections and egalitarian positions.

Thus, the results of this study have important implications because they draw attention to the need to deconstruct gender stereotypes, since that, in order to maintain the status $q u o$, even members of socially majority groups (e.g. men) may be subject to suffering prejudice and discrimination depending on their position in relation to relationships between men and women. For this reason, bringing these discussions into school settings and starting this deconstruction of roles with children and young people can be a crucial alternative for achieving breakthroughs in gender equality. A possible development of the results presented here is the planning of interventions with schools that aim to discuss and deconstruct the sexual division of roles. Thus, performing playful psycho-pedagogical interventions (e.g. role-playing games) that encourage role equality and the deconstruction that certain games or social responsibilities are unique to a particular gender can be very effective in combating gender inequality.

In the work context, this work can also help companies to encourage models of couples who work full time so that men also engage actively in household and family activities, contributing to the change in beliefs that housework should be performed only by women. In another aspect, but also effective, is to make companies aware that, by advertising their products, they remove stereotypical views of men and women in traditional activities and, in doing so, may contribute to changes in their consumers' paradigms and conceptions. Taken together, these possibilities for interventions point to the scientific and social relevance of the studies presented here.

However, it is important to note that some gaps were left by the studies presented here. One of the aspects that should be analyzed in future studies concerns the work context. Considering the alternative hypothesis that the results related to the competence dimension may have been influenced by the fact that the context used was a context perceived as masculine (Viana, 2016; Viana et al., 2018), additional studies should be conducted in feminine contexts or in neutral contexts.

A second important aspect that should be investigated in more detail concerns women's rights advocated by egalitarian targets. The right to maternity leave was mentioned here, which is one of the oldest guaranteed by law in Brazil. What would happen if the egalitarian target defended a more controversial right in Brazilian society, such as the right to abortion? Or paternity leave being enjoyed for the same period as maternity leave, since studies such as that by Albuquerque et al. (in press) demonstrate that when women become mothers they are judged by different standards in the workplace, compared to fathers. Another perspective that deserves investigation in future studies is the view of homosexuality and its impact on gender stereotypes. Finally, it is important to bear in mind that although these results have shown a relationship with the black sheep effect (Marques et al., 1988; Pinto et al., 2016), the impact of this effect was not directly investigated and deserves to be included in upcoming studies.

These ideas can undoubtedly contribute both to understanding the persistence of gender inequalities in Brazilian society and to helping pave the way for the construction of a more egalitarian society.

\section{References}

Abric, J. C. (2003). La recherche du noyau central et de la zone muette des représentations sociales. In J. C. Abric (Org.), Méthodes d'étude des représentations sociales (pp. 59-80). Saint-Agne: ÉRÈS.

Albuquerque, I. M., Torres, A. R. R., Álvaro, J. L., \& Garrido, A. (in press). Processos psicossociais de discriminação contra a mulher no âmbito laboral. Revista Colombiana de Psicología. 
Álvaro, J. L., \& Garrido, A. (2006). Psicologia Social: perspectivas psicológicas e sociológicas. Madrid: McGraw-Hill.

Amâncio, L. (2006). Identidade social e relações intergrupais. In Jorge Vala, Maria Benedicta Monteiro (Orgs.). Psicologia Social (pp.383-409). Lisboa: Fundação Calouste Gulbenkian.

Anderson, V. (2009). What's in a label? Judgments of feminist men and feminist women. Psychology of Women Quarterly, 33(2), 206-215. doi: https://doi. org/10.1111/j.1471-6402.2009.01490.x

Araújo, A. M. C., \& Lombardi, M. R. (2013). Trabalho informal, gênero e raça no Brasil do início do século XXI. Cadernos de Pesquisa, 43, 149, 452-477. doi: http://dx.doi. org/10.1590/S0100-15742013000200005

Bardin, L. (1977). Análise de conteúdo. Lisboa: Edições 70.

Barreto, M., \& Ellemers, N. (2015). Detecting and experiencing prejudice: new answers to old questions. Advances in Experimental Social Psychology, 52, 139-219. doi: http:// hdl.handle.net/10071/11715

Batista, J. R. M., Leite, E. L., Torres, A. R. R., \& Camino, L. (2014). Negros e Nordestinos: similaridades nos estereótipos raciais e regionais. Psicologia Política, 14(30), 325-345. http://pepsic.bvsalud.org/pdf/rpp/v14n30/ v14n30a08.pdf

Bergsieker, H. B., Leslie, L. M., Constantine, V. S., \& Fiske, S. T. (2012). Stereotyping by omission: Eliminate the negative, accentuate the positive. Journal of Personality and Social Psychology, 102(6), 1214-1238. doi: http://dx.doi. org/10.1037/a0027717

Benard, S. \& Correll, S.J. (2010). Normative Discrimination and the Motherhood Penalty. Gender \& Society, 24(5): 61646. doi: https://doi.org/10.1177/0891243210383142

Bosak, J., Sczesny, S., \& Eagly, A. H. (2012). The impact of social roles on trait judgments-acritical re-examination. Personality and Social Psychology Bulletin, 38(4), 429440. doi: https://doi.org/10.1177/0146167211427308

Bott, S., Guedes, A., Goodwin, M., \& Mendoza, J. A. (2012). Violence against women in Latin America and the Caribbean: A comparative analysis of population-based data from 12 countries. Washington, DC: Pan American Health Organization.

Burgess, N. (2013). "The Motherhood Penalty: How Gender and Parental Status Influence Judgements of Job-Related Competence and Organizational Commitment". Seminar Research Paper Series. 32. https://digitalcommons.uri.edu/cgi/viewcontent. cgi?article $=1035 \&$ context $=$ lrc_paper_series

Brambilla, B, Sacchi, S., Rusconi, P., Cherubini, P., \& Yzerbyt, V. Y. (2012). You Want to Give a Good Impression? Be Honest! Moral Traits Dominate Group Impression Formation. British Journal of Social Psychology, 51, 149166. doi: 10.1111/j.2044-8309.2010.02011.x
Brambilla, M., Rusconi, P., Sacchi, S., \& Cherubini, P. (2011). Looking for honesty: The primary role of morality (vs. sociability and competence) in information gathering. European Journal of Social Psychology, 41(2), 135-143. doi: 10.1002/ejsp.744

Brescoll, V. T., Uhlmann, E. L., Moss-Racusin, C. A., \& Sarnell, L. (2012). Masculinity, status, and subordi $\neg$ nation: Why working for a gender stereotype viola $\neg$ tor causes men to lose status. Journal of Experimental Social Psychology, 48, 354-357. doi: 10.1016/j.jesp.2011.06.005

Camargo, B. V., \& Justo, A. M. (2013). IRAMUTEQ: Um Software Gratuito para Análise de Dados Textuais. Temas em Psicologia, 21(2), 513-518. https://digitalcommons.uri.edu/cgi/viewcontent. cgi?article $=1035 \&$ context $=$ lrc_paper_series

Camino, L., Àlvaro, J. L., Torres, A. R. R.; Garrido, A., Morais, T., Almeida, J. (2013). Explaining social discrimination: Racism in Brazil and Xenophobia in Spain. The Spanish Journal of Psychology, 16 (E73), 1-13. doi: 10.1017/sjp.2013.65

Camino, L., Silva, P., Machado, A., \& Pereira, C. (2001). A face oculta do racismo no Brasil: uma análise psicossociológica. Revista de Psicologia Política, 1(1), 13-36. doi: https://doi.org/10.17771/PUCRio.acad.10498

Camino, L., Tavares, T. L., Torres, A. R. R., Álvaro, J. L., \& Garrido, A. (2014). Repertórios discursivos de estudantes universitários sobre cotas raciais nas universidades públicas brasileiras. Psicologia \& Sociedade, 26(n.sp.), 117-128. doi: http://dx.doi.org/10.1590/ S0102-71822014000500013

Chokier, N., \& Moliner, P. (2006). La « zone muette» des représentations sociales, pression normative et/ou comparaison sociale? Bulletin de Psychologie, 59(3), 281-286. doi: 10.3917/bupsy.483.0281

Connor, R. A., \& Fiske, S. T. (2018). Warmth and competence: A feminist look at power and negotiation. In C. B. Travis, J. W. White, A. Rutherford, W. S. Williams, S. L. Cook, \& K. F. Wyche (Eds.), APA handbooks in psychology. APA handbook of the psychology of women: History, theory, and battlegrounds (p. 321-342). American Psychological Association. doi: https://doi. org/10.1037/0000059-016

Connor, R. A., \& Fiske, S. T. (2019). Not Minding the Gap: How Hostile Sexism Encourages Choice Explanations for the Gender Income Gap. Psychology. Psychology of Women Quarterly, 43(1), 22-36. doi: 10.1177/0361684318815468

Costa-Lopes, R., Dovidio, J. F., Pereira, C. R., \& Jost, J. T. (2013). Social psychological perspectives on the legitimation of social inequality: Past, present and future. European Journal of Social Psychology, 43(4), 229-237. doi:10.1002/ ejsp. 1966

Costa-Lopes, R., \& Pereira, C. R. (2011). O impacto da norma anti-racista nas respostas a inquéritos sobre preconceito. 
Capítulo recuperado de https://www.researchgate.net/ publication/235920709

Cuadrado, I., López-Rodríguez, L., \& Navas, M. (2016). La perspectiva de la minoría: estereotipos y emociones entre grupos inmigrantes. Anales de Psicología, 32(2), 535-544. doi: http://dx.doi.org/10.6018/analesps.32.2.205341

Cuddy, A. J. C., Fiske, S. T., Kwan, V. S. Y., Glick, P., Demoulin, S., Leyens, J. Ph., ... Ziegler, R. (2009). Stereotype content model across cultures: Towards universal similarities and some differences. British Journal of Social Psychology, 48(1), 1-33. doi: https://doi. org/10.1348/014466608X314935

Doise, W. (2002). Da Psicologia Social à Psicologia Societal. Psicologia: Teoria e Pesquisa, 18(1), 27-35. doi http:// dx.doi.org/10.1590/S0102-37722002000100004

Doise, W. (1986). Levels of explanation in social psychology. Cambridge: Cambridge University Press.

Eagly, A. H., \& Karau, S. J. (2002). Role congruity theory of prejudice toward female leaders. Psychological Review, 109(3), 573-598. doi: http://dx.doi. org/10.1037/0033-295X.109.3.573

Eagly, A. H., \& Steffen, V. J. (1984). Gender stereotypes stem from the distribution of women and men into social roles. Journal of Personality and Social Psychology, 46(4), 735754. doi: http://dx.doi.org/10.1037/0022-3514.46.4.735

Ellemers, N. (2018). Gender Stereotypes. Annual Review of Psychology, 69(1), 275-298. doi: https://doi.org/10.1146/ annurev-psych-122216-011719

El País. (2019). Carga mental: a tarefa invisível das mulheres de que ninguém fala. Retirado de: https://brasil.elpais.com/ brasil/2019/03/01/politica/1551460732_315309.html

Ferreira, A. S. S., Leite, E. L., Sousa, A. W. L., Álvaro, J. L., \& Torres, A. R. R. (2017). Repertórios interpretativos acerca do preconceito racial no futebol. Estudos de Psicologia, 22(3), 338-348. doi: http://dx.doi. org/10.22491/1678-4669.20170034

Field, A. (2006). Discovering Statistics Using SPSS. London: Sage Publications.

Fiske, S. T. (1998). Stereotyping, prejudice, and discrimination. In D. T. Gilbert, S. T. Fiske \& G. Lindzey (Eds.), The handbook of social psychology (4 ${ }^{\mathrm{a}} \mathrm{Ed}$., Vol. 2, pp. 357-411). Boston: McGraw-Hill.

Fiske, S. T., Cuddy, A. J. C., Glick, P., \& Xu, J. (2002). A model of (often mixed) stereotype content: Competence and warmth respectively follow from perceived status and competition. Journal and Personality and Social Psychology, 82(6), 878902. doi: http://dx.doi.org/10.1037/0022-3514.82.6.878

Fiske, S. T., Xu, J., Cuddy, A., \& Glick, P. (1999). (Dis)respecting versus (dis)liking: Status and interdependence predict ambivalent stereotypes of competence and warmth. Journal of Social Issues, 55(3), 473-491. doi: https://doi. org/10.1111/0022-4537.00128
Flament, C., \& Milland, L. (2010). La substitution dans les études des représentations sociales: quel processus impliqué? Psychologie Française, 55(3), 195-210. doi: https:// doi.org/10.1016/j.psfr.2010.05.003

Fontoura, N., Rezende, M. T., Mostafa, J., \& Lobato, A. L. (2017). Retrato das desigualdades de gênero e raça - 1995 a 2015. Instituto de Pesquisa Econômica Aplicada (IPEA). Retirado de:http://www.ipea.gov.br/portal/images/stories/ PDFs/170306_retrato_das_desigualdades_de_genero_raca. pdf

Garcia-Alonso, J., Krentz, M., Lovich, D., Quickenden, S., \& Taplett, F. B. (2019). Lightening the mental load that holds women back. Boston Consulting Group, 1-6. Retirado de: https:/www.google.com/url?sa=t\&rct=j $\& \mathrm{q}=\&$ esrc $=\mathrm{s} \&$ source $=$ web $\& \mathrm{~cd}=2 \& \mathrm{cad}=\mathrm{rja} \&$ uact $=8 \&$ ved=2ahUKEwjV_eK8nLnmAhXgGLkGHXgDCPM QFjABegQIBRAC\&url=http\%3A\%2F\%2Fimage-src. bcg.com $\% 2$ FImages $\% 2$ FBCG-Lightening-the-MentalLoad-That-Holds-Women-Back-Apr-2019_tcm9-217471. pdf\&usg=AOvVaw11Gp9nH_NrtRnLtNXRloH9

Garrido, A., Álvaro, J. L., \& Torres, A. R. R. (2018). Estereotipos de género, maternidad y empleo: un análisis psicológico. Pensando Psicología, 14(23). doi: https://doi.org/10.16925/ pe.v14i23.2261

Gelman, S., \& Wellman, W. (1991). Insides and essences: early understand-ings insides and essences of the nonobvious. Cognition, 38(3), 213-244. doi: https://doi. org/10.1016/0010-0277(91)90007-Q

Gocłowska, M. A., Crisp, R. J., \& Labuschagne, K. (2012). Can counter-stereotypes prime flexible thinking? Group Processes and Intergroup Relations, 16(2), 217-231. doi: https://doi.org/10.1177/1368430212445076

Guedes, M. C.; Araújo, C. (2011). Desigualdades de gênero, família e trabalho: mudanças e permanências no cenário brasileiro. Revista Gênero, 12(1), 61-79. doi: https://doi. org/10.22409/rg.v12i1.394

Guimelli, C., \& Deschamps, J. C. (2000). Effet des contextes sur la production d'associations verbales. Le cas des représentations sociales des Gitanes. Les Cahiers Internationaux de Psychologie Sociale, 47(3), 44-54. Retirado de: Retirado de: http://www.academia.edu/download/5399477/2000 guimelli_deschamps.pdf

Hair, J. F., Jr., Black, W. C., Babin, B. J., \& Anderson, R. E. (2010). Multivariate data analysis (7. ed.). Upper Side River: Prentice Hall.

Heilman, M. E., \& Wallen, A. S. (2010). Wimpy and underserving of respect: Penalties for men's gen $\neg$ der-inconsistent success. Journal of Experimental Social Psychology, 46(4), 664-667. doi: https://doi.org/10.1016/j.jesp.2010.01.008

Hirata, H. (2015). Mudanças e permanências nas desigualdades de gênero: divisão sexual do trabalho numa perspectiva comparada. Friedrich Ebert Stiftung Brasil, 7, 4-22. https:// library.fes.de/pdf-files/bueros/brasilien/12133.pdf 
Instituto de Geografia e Estatística - IBGE. (2018). Estatísticas de gênero: indicadores sociais das mulheres no Brasil. Estudos \& pesquisas: informação demográfica e socioeconômica, 38, 1-12. https://biblioteca.ibge.gov.br/visualizacao/livros/liv101551_informativo.pdf

Leach, C. W., Ellemers, N., \& Barreto, M. (2007). Group virtue: The importance of morality (vs. competence and sociability) in the positive evaluation of ingroups. Journal of Personality and Social Psychology, 93(2), 234-249. doi: http://dx.doi.org/10.1037/0022-3514.93.2.234

Lima, L. L. B. (2011). A masculinização da mulher líder no Brasil: quatro estudos sobre estereótipos de gênero e protótipos de liderança. Dissertação de mestrado apresentada a Escola Brasileira de Administração Pública e de Empresa da Fundação Getúlio Vargas. Fundação Getúlio Vargas - São Paulo. Retirado de: https://bibliotecadigital.fgv.br/ dspace/handle/10438/8633

Lima, M. E. O. (2013). Preconceito. In: A. R. R. Torres, L. Camino, M. E. O. Lima \& M. E. Pereira (Eds.), Psicologia Social: Temas e Teorias (2nd ed., Vol. 1, pp. 589-642). Brasília: Techonopolitik.

López-Rodríguez, L., Cuadrado, I., \& Navas, M. (2013). Aplicación extendida del Modelo de Contenido de Estereotipos (MCE) hacia tres grupos de inmigrantes en España. Estudios de Psicología, 34(2), 197-208. doi: https:// doi.org/10.1174/021093913806751375

Marôco, J. (2011). Análise Estatística com o SPSS Statistics. (5 Ed). Lisboa: ReportNumber.

Marques, J. M., Yzerbyt, V. Y., \& Leyens, J.-P. (1988). The black sheep effect: Extremity of judgmental towards ingroup members as a function of group identification. European Journal of Social Psychology, 18(1), 1-16. doi: http://dx.doi.org/10.1002/ejsp.2420180102

Méndez, C. L. (1995). Violencia en la pareja. Em H. Maturana; F. Coddou; H. Montenegro; G. Kunstmann e C. L. Méndez (Orgs.). Violencia en sus distintos ambitos de expression (pp. 23-38). Santiago: Dolmen Ediciones.

Moreno, A. C. (2017). Porcentagem de mulheres nas faculdades de engenharia civil cresce mais do que o número de engenheiros no mercado. Recuperado de: https://g1.globo. com/educacao/guia-de-carreiras/noticia/porcentagem-demulheres-nas-faculdades-de-engenharia-civil-cresce-maisque-n-de-engenheiras-no-mercado.ghtml

Nogueira, C. (2010). As mulheres na liderança. Números, ambiguidades e dificuldades. In Teresa Pinto (Coord.) et al., Guião de Educação. Género e Cidadania. $3^{\circ}$ ciclo do ensino básico (pp. 103-114). Lisboa: CIG.

Pereira, M. E., Álvaro, J. L., \& Garrido, A. (2016). Procesos de esencialización de hombres y mujeres: Unestudio comparado Brasil-España. Anales de Psicología, 32(1), 190-198. doi: http://dx.doi.org/10.6018/analesps.32.1.190841

Pereira, C., \& Vala, J. (2007). Preconceito, normas sociais e justificações para a discriminação de pessoas de cor negra. In J. Vala, M. Garrido, \& P. Alcobia (Eds.), Percursos da investigação em psicologia social e organizacional (2nd ed., Vol. II, pp. 145-164). Lisboa: Edições Colibri.

Pereira, C., Vala, J., \& Costa-Lopes, R. (2010). From prejudice to discrimination: The legitimizing role of perceived threat in discrimination against immigrants. European Journal of Social Psychology, 40(7), 1231-1250. doi:10.1002/ejsp

Pinto, I. R., Marques, J. M., Levine, J. M., \& Abrams, D. (2016). Membership role and subjective group dynamics: Impact on evaluative intragroup differentiation and commitment to prescriptive norms. Group Processes \& Intergroup Relations, 19(5), 570-590. doi: https://doi. org/10.1177/1368430216638531

Ratinaud, P. (2009). Iramuteq: Interface de R pour les analyses multidimensionnelles de textes et de questionnaires (computer software). Recuperado de http://iramuteq.org

Reinert, M. (1990) Alceste, une méthodologie d'analyse des données textuelles et une application: Aurelia de Gerard de Nerval. Bulletin de Methodologie Sociologique, 26, 24-54. DOI:10.1177/075910639002600103

Rudman, L. A., \& Mescher, K. (2013). Penalizing men who request a family leave: Is flexibility stigma a femininity stigma? Journal of Social Issues, 69(2), 322-340. doi: https:// doi.org/10.1111/josi.12017

Rudman, L. A., Mescher, K., \& Moss-Racusin, C. A. (2012a). Reactions to gender egalitarian men: Perceived feminization due to stigma-by-association. Group Processes \& Intergroup Relations, 16(5), 572-599. doi: https://doi. org/10.1177/1368430212461160

Rudman, L. A., Moss-Racusin, C. A., Phelan, J. E., \& Nauts, S. (2012b). Status incongruity and backlash effects: Defending the gender hierarchy motivates prejudice toward female leaders. Journal of Experimental Social Psychology, 48, 165-179. doi: https://doi.org/10.1016/j.jesp.2011.10.008

Salviati, M. E. (2017). Manual do aplicativo Iramuteq. Planaltina, DF: Embrapa Cerrados.

Tabachnick, B. G., \& Fidell, L. S. (2001). Using Multivariate Statistics. (4 ed.). Boston: Allyn and Bacon.

Tajfel, H. (1978). Differentiation between social groups: studies in the social psychology of Intergroup Relations. London: Academic Press.

Tajfel, H. (1981). Grupos humanos e categorias sociais (Vol. 1 e 2). Lisboa: Livros Horizonte.

Tajfel, H., \& Turner, J. C. (1986). The social identity theory of intergroup behaviour. In W. G. Austin \& S. Worchel (Eds.), Psychology of intergroup relations (2nd ed.), (pp. 7-24). Chicago: Nelson-Hall.

Torres, A. R. R., \& Camino, L. (2013). Grupos Sociais, Relações Intergrupais e Identidade Social. In: L. Camino, A. R. R. Torres, M. E. O. Lima \& M. E. Pereira (Eds.). Psicologia Social: Temas e Teorias (2nd ed., Vol. 1, pp. 513-538). Brasilia: Technopolitik.

Viana, H. A. (2016). Sexismo na docência universitária: evidências da persistência do estereótipo de gênero. Dissertação 
não publicada. João Pessoa: Universidade Federal da Paraíba, Programa de Pós-graduação em Psicologia Social.

Viana, H. A., Sousa, A. W. L., \& Torres, A. R. R. (2018). Engenheiras e enfermeiros: estereótipos, discriminação e desafios de profissionais contranormativos. Interdisciplinar, 29, 25-56. Retirado de: https://seer.ufs.br/index.php/ interdisciplinar/article/view/9623/7456

Williams, J. C., Berdahl, J. L., \& Vandello, J. A. (2016). Beyond work-life "integration." Annual Review of Psychology, 67(1), 515-39. doi: https://doi.org/10.1146/ annurev-psych-122414-033710
World Economic Forum (2017). The Global Gender Gap Report. ISBN I978-1-944835-12-5. Retirado de: http:// www3.weforum.org/docs/WEF_GGGR_2017.pdf

Zurutuza, C. (1993). Breve introdução teórica ao tema "violência contra a mulher em relações de casal". Em Red Nacional por la Salud de la Mujer-Argentina (Org.). Entre pildoras, mandatos y emociones (pp. 90- 120). Buenos Aires: RED. 